\title{
DEDICATION
}

\section{CHEAH BOON KHENG (1939-2015) IN MEMORIAM}

\author{
Abu Talib Ahmad \\ School of Humanities, Universiti Sains Malaysia, Penang, MALAYSIA \\ Email: atalib@usm.my
}

Published online: 25 September 2017

To cite this article: Abu Talib Ahmad. 2017. Cheah Boon Kheng (1939-2015) in memoriam. Kajian Malaysia 35(2): 127-130. https://doi.org/10.21315/km2017.35.2.7

To link to this article: $\mathrm{https} / / /$ doi.org $/ 10.21315 / \mathrm{km} 2017.35 .2 .7$

Cheah Boon Kheng was already a well known historian when I first met him at the staff canteen within the School of Humanities/Social Sciences in early 1985. I had reported for duty in early December the previous year but he was away in Yale University as a Fullbright Visiting Research Fellow. His impeccable reputation notably among international scholars was contributed by the two books, the Masked Comrades: A Study of the Communist United Front in Malaya, 1945-48 (1979) and Red Star Over Malaya: Resistance and Social Conflict during and after the Japanese Occupation, 1941-46 (1983) which have received critical reviews among scholars of Southeast Asia. By the first decade of the 21st century he had written three more books The Peasant Robber of Kedah, 1900-1929: Historical and Folk Perceptions (1988), To' Janggut: Legends, Histories and Perceptions of the 1915 Rebellion in Kelantan (2006), and Malaysia: The Making of a Nation (2002). In addition, he had also edited a number of major works and essays, many of which were published in the Journal of the Malaysian Branch of the Royal Asiatic Society (JMBRAS), covering various aspects of Malaysian history that have been widely consulted. A few of these books such as Red Star over Malaya, the Peasant Robbers of Kedah and To'Janggut went through several editions. Although I was not aware of who Boon Kheng was during our first encounter, which was facilitated by another senior colleague, the late R. Suntharalingam, it marked the beginning of a fruitful relationship that went beyond Boon Kheng's retirement from Universiti Sains Malaysia (USM) in 1994 as professor of Malaysian history. He had joined the university in 1978 after completing his MA at the University of Malaya. Within the History Section we got along well as attested by the two books we edited together in 1990 and 1995. With his encouragement, I organised a course on the Japanese Occupation of Southeast Asia which was well subscribed as it involved the use of oral history. At one point both of us were elected as members of the university senate by the School of Humanities and some of the issues we 
raised in senate proceedings were the small funding allocated for research in the humanities and social sciences compared to the sciences.

As a newbie, I learnt much from Boon Kheng (and his close friend Suntharalingam). His field was Malaysian social and political history focusing on groups that were excluded from the national narrative but Boon Kheng was very much aware of what was happening in other fields of research and history from below, an emerging paradigm in historical research, as evidenced in his foray into social banditry in Kedah and the Tok Janggut rebellion of Kelantan. He took much efforts to disseminate these to colleagues and students. Younger colleagues later incorporated some of his ideas in new course offerings for undergraduates. He was also instrumental in the section's publication project and assidously kept it going. Between 1984-1995 the project managed to produce four publications and Boon Kheng was closely associated with two of them Kolonialisme dan Imperialisme: Satu Tinjauan Sejarah (Fajar Bakti: 1990) and Isu-isu dalam Pensejarahan (Penerbit USM: 1995). We were editors for both volumes. Isu-isu dalam Pensejarahan was a festschrift for Associate Professor R. Suntharalingam who retired in October 1991. In July 1995 Suntharalingam was given copies of the book by Boon Kheng and the former recorded the following thought on the matter.

\begin{abstract}
Although I have known for some time that this commemorative volume was in preparation, I must confess that I was not fully aware of all its implications. However, now that the book is published, it is evident to me that you have done me an honour that I do not really deserve. The fact that such honour is rarely bestowed, and bestowed only on those with distinguished academic record, has stirred within me a deep feeling of inadequacy. This feeling has also been reinforced by the willingness of so many people to contribute to this project. To be frank, I had only expected a slim volume with about half a dozen contributors. After all, one can hardly expect academics burdened with teaching and research responsibilities to find time to write for a commemorative volume.
\end{abstract}

In the above publications, Boon Kheng had made it a point to include the best long essays completed by his students; one covers Pekan Cina in Alor Setar and the other a critique of Hobson-Lenin on British colonialism in Pahang. In fact such efforts had begun earlier in 1982 when he and another colleague, Paul Kratoska, each edited a collection of student long essays on Malaysian history under the theme local leaders and migrant and migration. Both these compendium were published as part of the occasional paper series under the School of Humanities. He was also part of the USM Oral History Project which was set up in 1982. The project covers the Japanese Occupation in north Perak, Penang, Kedah and Perlis. The project went on to publish a few interviews of respondents pertaining to the Japanese Occupation; Boon Kheng contributed one to the project through 
the interview (along with Datuk Dr. Sharom Ahmat) with Tunku Abdul Rahman which was later published by USM as Reminiscences of Tunku Abdul Rahman on the Japanese Occupation, 1941-1945 (1989).

Cheah Boon Kheng retired in 1994 and accepted visiting positions at the National University of Singapore (NUS) (for a year at the History Department), Australian National University and the Institute of Southeast Asian Studies, Singapore. He was also invited as visiting professor at the School of Humanities, USM for a year to give lectures and to encourage research. One impact of this presence was the publication of a book titled New Perspectives and Research on Malaysian History that he edited and which was published by the Malaysian Branch of the Royal Asiatic Society (MBRAS) in 2007. This book managed to link up for the first time historians from USM (Abu Talib Ahmad, Badriyah Haji Salleh, Mahani Musa, Haryati Hassan and Nik Haslinda Nik Hussain), Universiti Malaya (Hamidin Abdul Hamid, Loh Wei Leng and Danny Wong Tze Ken) and NUS (Paul H Kratoska). Such collaboration was made possible only by a scholar of Boon Kheng's stature.

Malaysian social history as taught by Boon Kheng attracted many students who were exposed to the discipline of history in a novel way by familiarising them with myriad viewpoints and to debate on them. His lectures were easy to understand and students have attested that he valued their viewpoints. He had also supervised postgraduate students who later went on to make a name for themselves in Malaysian history. A few of his students include Nabir Haji Abdullah, Mohd Isa Othman and Julie Tang Su Chin while others benefitted indirectly through his patient counsel and discussions. Between 1990-1993 he was editor of Kajian Malaysia and through contacts with international scholars he continued to maintain Kajian Malaysia's visibility and acceptance among the global academic fraternity notably those from the social sciences and humanities.

One interesting facet of his academic career was the ability to attract international scholars, many of them personal acquaintances, to visit the School of Humanities and to present seminars on a variety of interesting topics. Notable luminaries who have given honour to the school through their visits include Anthony Reid, Anthony Milner, and Hendrik Maier. These seminars attracted much crowd including those from the social sciences. In a way it reminds me of the Monash weekly seminars that were always well attended and served to introduce postgraduate students to exciting new research and scholars of Southeast Asia.

Cheah Boon Kheng had a long involvement with MBRAS. Between 1985-1990 he was a member of the MBRAS council; MBRAS at the time was led by Tan Sri Mubin Sheppard. Between 1990-1999 he was one of its vice president. Later he went on to become the editor of the society's journal (JMBRAS) until ill health forced his retirement in late 2014. I am not sure who suggested the Mubin Sheppard Memorial Essays contest but as JMBRAS editor, Boon Kheng was 
responsible to see the publications of selected academic exercises (and MA thesis). To his credit Boon Kheng managed to get a few of them published by JMBRAS starting with Kongsi Gelap Melayu di-Negeri Utara Pantai Barat Semenanjung Tanah Melayu, 1821 hingga 1940-an by Mahani Musa (2003), Masalah-masalah Setinggan Cina di Daerah Ulu Langat Selangor pada Masa Darurat by Wong Siew Kuon (1999), A History of Diplomacy and Trade in Nineteenth Century Labuan by Beatrice Chong (1999), and Studies in Malaysian \& Singapore History which was edited by Bruce Lockdhard and Lim Tse Tsiang (2010). Later he delegated the task to another member of the council Dr. Badriyah Haji Salleh who managed to publish Di Antara Dasar dan Kesan: Hubungan Ekonomi, Penduduk dan Penyakit di Tanah Melayu di bawah Pentadbiran British (2013). Following Badriyah's retirement from MBRAS, I was elected into the council. Soon after I was asked by Boon Kheng to handle the Mubin Sheppard Memorial essays and managed to edit Perniagaan Haji di Pulau Pinang dan Dokumentasi Sultan Kedah in 2015. Working with him on the essays was an experience that I will never forget. As JMBRAS editor he was meticulous and this includes the technicalities of editing an academic work.

Outside the office, we did not meet much although once in a while he would throw a party for colleagues and students alike at his house in Minden Heights. I was deeply honoured to be invited to his son's wedding in Penang which took place in a church opposite the Penang Free School. At other times the section would organise a dinner outing at a restaurant in town for visiting academics. These were the few occasions when one would see a different Boon Kheng. He used to play badminton regularly with USM staff but this stopped after his bypass operation many years ago. Since his move to the Klang Valley we did not meet often except during the MBRAS council meeting. A few years ago we met outside a food court located near the university in Sungai Dua. He was on a visit to Penang with family members - wife Ai Lin, son Lu Shun, daughter-in-law and granddaughter. The last meeting took place at his house in Bukit Kemuning, Shah Alam one Saturday afternoon just a few weeks before his demise in 2015. Prior to the MBRAS council meeting in the afternoon another colleague was generous enough to take me to his residence. Located in a quiet neighbourhood the corner double storey house was bought a few years earlier from a former vice chancellor of University Utara Malaysia. It was a joyful meeting interspersed with nostalgia. Ai Lin served tea and sweets. In that short meeting we talked about many things including current research and the History Section. As usual he was keenly interested for updates on the section, its members and so forth which I willingly supplied. We could not possibly stay long because of his health. A few weeks later he passed away on 21 July 2015 and the funeral drew colleagues from as far as Australia. Much to my regret I failed to make the trip due to an engagement in the university but I pray may his soul rest in peace. 